\title{
FUNCTIONAL LAND AND EMOTIONAL LANDSCAPE. DRY STONE CONSTRUCTIONS IN LA GARRIGA D'EMPORDÀ IN THE 19TH CENTURY
}

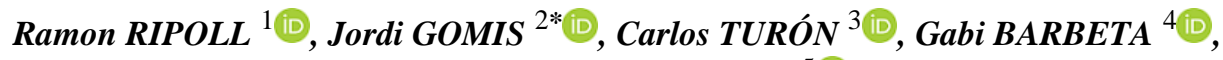 \\ Miquel-Àngel CHAMORRO ${ }^{5}$
}

DOI: 10.21163/GT_2021.162.13

\begin{abstract}
:
The relationship between traditional farmers with the physical characteristics of the site (material function) has long been analysed, but rarely has farmers' cultural relationship with their geographical environment (emotional function) been upheld. To demonstrate this duality implies finding farmland created both due to material profitability or family subsistence and due to psychological necessity or personal self-realization. For example, the transformation in the nineteenth century of desolate, stony unproductive landscapes in la Garriga d'Empordà -Catalonia- (of some $8 \mathrm{~km}^{2}$ ) into farmland, for poorer peasant families meant not only a minuscule means of material progress but above all a major means of social hope and human dignity. To confirm this duality is to corroborate that many functional territories are also emotional landscapes for those who farm them, mainly during the period of major agricultural expansion in Europe due to the growth in population at the onset of the modern era.
\end{abstract}

Key-words: Regional poverty, Usable land, Variable plots, Dry stone, Landscape.

\section{INTRODUCTION}

The following analysis of la Garriga d'Empordà defines a local situation that is also a reflection of global concepts. It seeks to demonstrate the relationship between natural geography and agricultural geography especially in highly unfavourable situations (regional poverty), the legal uniqueness, of medieval origin, of access to land (beneficial ownership/usufruct), the parallels between social regeneration and the democratization of private property (variable geometry), the construction work done by the agricultural workers themselves (dry stone), obtaining supplementary agricultural income by the most neglected rural families and, finally, to underline the hypothesis of personal self-realization developed in parallel. So, the purpose of this article is to enrich the general concepts based on an example of agricultural transformation (la Garriga d'Empordà).

The interest in this subject lies in delving into the geographical, historical and agricultural reasons justifying first its emergence and then its abandonment. Hence, the paper begins with the introduction that relates population growth to employment in agriculture, continuing with the relationship between the legal systems governing access to property and social emancipation, the organic organization of the territory and the variable geometry of its ownership and, finally, territorial transformation and building technology.

\footnotetext{
1,4, 5 Universitat de Girona, C/Maria Aurèlia Capmany 61, 17003-Girona, Spain, ramon.ripoll@udg.edu,gabriel.barbeta@udg.edu,mangel.chamorro@udg.edu

${ }^{2,3}$ Universitat Rovira i Virgili, Av.Països Catalans 26, 43007-Tarragona, Spain, ${ }^{*}$ jordi.gomis@urv.cat, carlos.turon@urv.cat
} 
The methodology used is based on surveying plans of the most representative elements, studying the territory from the existing cartography, research at the notarial archives of lease contracts, and lastly, the theoretical analysis of the concepts raised. Regarding the latter, it is worth mentioning the spatial concepts of the humanization of space such as organic form, variable geometry, etc. (Aalto, 1977); the survival of the characteristics of one era over another through rupture, transition, cohabitation, etc; and on the democratization of agriculture, preindustrial farming, etc. (Terrades, 1984).

\section{REGIONAL POVERTY}

First, let us recall the great population growth during the nineteenth century which explains the increase in farmed land and, therefore, the widespread use of land for agricultural purposes. Improvements in hygiene, diet and medicine during this period led the population to double in few years. Specifically, in the Alt Empordà region in Catalonia, where the study area, la Garriga, is located, the population almost doubled in less than a century. It went from 41,280 inhabitants in 1787 to 73,867 in 1857 (i.e., an increase of $79 \%$ in seventy years). It should be mentioned that this calculation does not include the first migratory movements from rural parts of the Empordà to the city. This means that the population of Alt Empordà increased 6\% less than the growth rate of Catalonia during these 70 years $(899,531$ to $1,661,291$ inhabitants). This increase in population is related to the expansion of vineyards and olive groves to poorer, inland mountainous areas. All of this would suggest that the land area devoted to farming reached its peak in Catalonia in the midnineteenth century (Congost, 1999).

Such demographic expansion allowed the entire population to grow, and especially agricultural workers, salaried farmers and labourers, who earned a living by doing temporary work (quarries, forests and crops). These workers either owned nothing (had no land) or they had very small properties (small plots), and were forced to perform temporary, precarious, irregular work. This socioeconomic situation underlies the agricultural transformation of the area of la Garriga d'Empordà formed by several municipalities (Avinyonet de Puigventós, Vilanant, Llers...), characterized by being relatively flat (between 125 and $218 \mathrm{~m}$ above sea level), classified as dry and low rainfall (between 400 and $1,000 \mathrm{l} / \mathrm{m} 2$ per year), mostly covered in stone (limestone), located near the sea $(20 \mathrm{~km})$ and exposed to the north wind (that can reach speeds of $130 \mathrm{~km} / \mathrm{h}$ ).

It should be noted that this agricultural transformation (mass planting of vineyards and olive groves) took place through interventions in small-scale farms. Each such property was transformed and farmed by a labourer who either owned or leased the land. Such agricultural organization lasted until the late nineteenth century, which is when olive trees completely replaced vineyards as a result of the arrival of the phylloxera plague (in 1879). The predominant olive cultivation continued until the mid-twentieth century when these microcrops started to be abandoned, again for socioeconomic reasons.

The consequences of this agricultural intervention at la Garriga d'Empordà (Fig. 1), in the nineteenth and in the first half of the twentieth centuries, was the creation of surprising historical heritage made of retaining walls and dry-stone walls as well as vineyard huts and access roads made implementing the dry-stone construction technique. Undoubtedly, upholding the dual, material and mental function of this surprising agricultural transformation (both due to its extent and speed of execution) especially requires answering the questions: What was the influence between legislation and the democratization of property? What is the significance of the variable geometry of the space territory-? How does the dry-stone construction technique revalorize the territory? What psychological ties between the person who transforms and the landscape transformed last in time?

It should be noted that this agricultural transformation (mass planting of vineyards and olive groves) took place through interventions in small-scale farms. Each such property was transformed and farmed by a labourer who either owned or leased the land. Such agricultural organization lasted until the late nineteenth century, which is when olive trees completely replaced vineyards as a result of the arrival of the phylloxera plague (in 1879). 

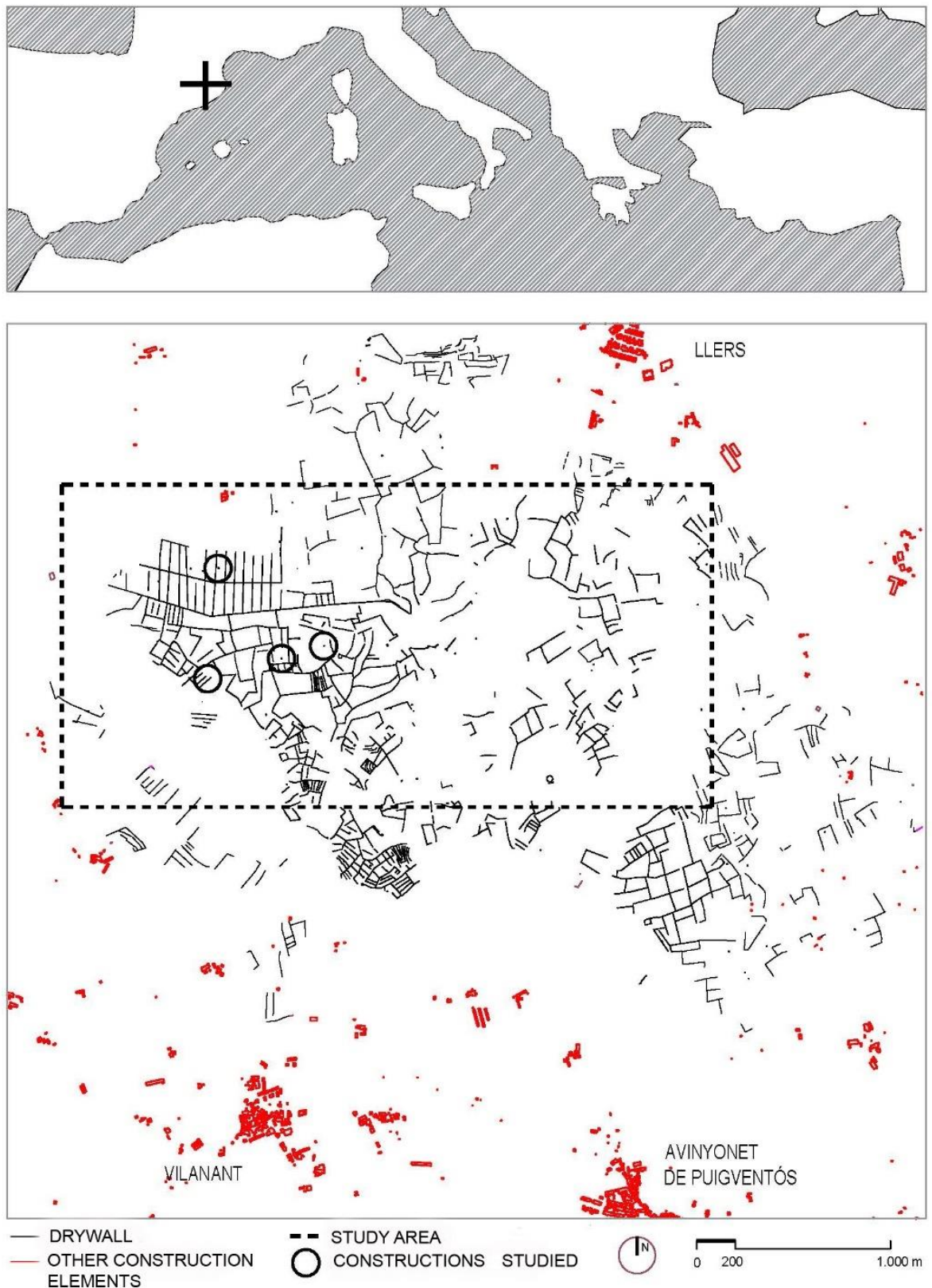

Fig. 1. Situation and location of la Garriga d'Empordà (drawing R. Ripoll, private archive, 2020).

The predominant olive cultivation continued until the mid-twentieth century when these microcrops started to be abandoned, again for socioeconomic reasons. The consequences of this agricultural intervention at la Garriga d'Empordà, in the nineteenth and in the first half of the twentieth centuries, was the creation of surprising historical heritage made of retaining walls and dry-stone walls as well as vineyard huts and access roads made implementing the dry-stone construction technique. Undoubtedly, upholding the dual, material and mental function of this surprising agricultural transformation (both due to its extent and speed of execution) especially requires answering the questions: 
What was the influence between legislation and the democratization of property?

What is the significance of the variable geometry of the space -territory-?

How does the dry-stone construction technique revalorize the territory?

What psychological ties between the person who transforms and the landscape transformed last in time?

In terms of practical research, a large number of general, simply descriptive studies have been performed in most countries including Italy, France, Germany, Ireland, Croatia, Cyprus, Greece, Malta, Catalonia, etc. (Miralles et al, 2002), with very partial, always fragmented contributions. Moreover, in terms of historical investigation, fewer studies have been conducted, though they go into greater depth. In the case of Catalonia concrete studies on land and areas of dry stone in the preindustrial period are important and explain the circumstances behind the fortune amassed by farmers, the desire of temporary rural workers to have land, etc. (Congost \& To, 1999). Meanwhile, there is a lack of studies that relate dry stone with the transformation of the landscape in the nineteenth century and the new cultural and personal relations with the region, barring highly isolated cases (McHarg, 2000). This situation amply justifies this research and its goal of relating practical, historical and cultural analysis with dry stone constructions at the same time. Thus, the aim is to provide new data on the dynamics of rural Catalonia in the nineteenth century and redefine social models (Congost, 2008). Also, based on unpublished sources, it seeks to look in greater depth into the importance of personal self-realization and psychological well-being of rural workers which, according to some authors, led to a new way of existence in the world (Aguiló, 1999). Thus arises the cultural concept of the place, according to Aristotelian thought of location mixed between private and common space (Artigas \& Sanguineti, 1993), both the result of territorial transformation and personal self-realization. This duality is advocated generally by some authors (Berque, 2009) or is intentional, according to other scholars (Ballart, 2018). Novel research, in view of the work conducted to date, anticipating such highly topical statements as equality between fieldwork and natural laws (Boada \& Zahonero, 1999), the landscape as a system of organized, interacting elements (De Bolós, 1992), multi-sensory presence in territorial transformations at the beginning of the modern era (De Castro,1997), and even the superimposition of various levels in regional life: natural, agricultural, social and personal (Berque, 2009). Specifically, the 316 plots of our selected sample have been studied, and their perimeter geometrical characteristics have been studied (shape, surface area and elevations), as well as the constructive characteristics of their dry stone walls (shape, length and thickness). These data describe the types of plots and their location. This work method has been based on the consultation of sources such as: cadastral plans, graphic documentation of the Cartographic Institute of Catalonia, aerial photographs from different years, as well as direct surveys of multiple dry stone constructions. The plans presented were made specifically by the team that drafted this article without resorting to any external references. On a theoretical level, the entire Comptadoria d' Hipoteques property register of the Girona Archive has been trawled to obtain plot lease contracts in the nineteenth century in La Garriga d'Emporda (tenant name, place of origin, cost, years of lease, leased surface area, etc.).

\section{DEMOCRATIZATION OF PROPERTY (BENEFICIAL OWNERSHIP AND LEASE)}

Catalan law dating back to the early medieval period extends up to the nineteenth century. This is first through emphyteusis (Congost, 2010), or the purchase of a small rural property, and second through contracts for the lease of a piece of land. Thus, the first legal means available to the farm labourer or small farmer to access land (from the late medieval to well into the contemporary era) is certainly the purchase of the beneficial ownership of a small agricultural property. In this case the landlord, who owns a large expanse of land (legal title), grants unlimitedly, perpetually or over a very long time, a piece of land to the buyer worker or farmer to work, farm and use it (beneficial ownership) in exchange for an annual payment or emphyteutic lease (according to the Arbitral Decision of Guadalupe of 1486 that allows unlimited beneficial ownership).

Thus, the two types of owners (title and beneficiary) do not cancel each other out but rather complement each other. The complexity of this system, the lack of the landlord's control over the 
farmers, as well as political, social and economic changes over the centuries all favoured farmers enjoying beneficial ownership and harming the interests of the legal title-holding landlords. And it is precisely in this general decline of legal title to property that most mass sales took place (mediumand small-sized parcels of land) with beneficial ownership rights to farm workers and small farmers of small pieces of land in la Garriga d'Empordà. Specifically, the cadastral register of 1736 declares $7,350 \mathrm{~m} 2$ (3.5 vessanes) of olive trees and 39,900 $\mathrm{m} 2$ (19 vessanes) of vineyards, and similar amounts are declared in 1808. However, by 182612 times more was declared (567,000 m2, or 280 vessanes) between vineyards and olive trees in the area of la Garriga d'Empordà. (Fèlix, 2012). The second legal means of access is through the traditional lease of a piece of land. In this case it is usually rented from the farmer of the beneficial ownership that has excess farmland or waste land and forests. In the case of la Garriga d'Empordà, leases of medium- and small-sized plots of land were practised (Congost, 2010). Among the most important properties in the area, we must mention Comella farm, in Vilanant, as an example of the management and sale of the beneficial ownership of plots in la Garriga d'Empordà. The management of land lease is also very significant of Mas Molar farm, in Llers, from the mid-nineteenth century, and is still clearly visible today. In this case, 28 rectangular parcels can be identified with a width: depth ratio of 1:2.5 to 1:3.5 (1:3 on average) and surface areas ranging from 5,634 $\mathrm{m} 2$ to 9,368 $\mathrm{m} 2$ (averaging 7,754 m2). Specifically, it is documented that in the midnineteenth century (26-10-1851) the owner of Mas Molar (Antoni Molar) leased eight parcels for a short time (five years) to different villagers (Fig. 2). The description of the rental sets out that seven of them have a surface area of three vessanes and one has four (always with the wording "more or less") (AHG, 1841-1862).

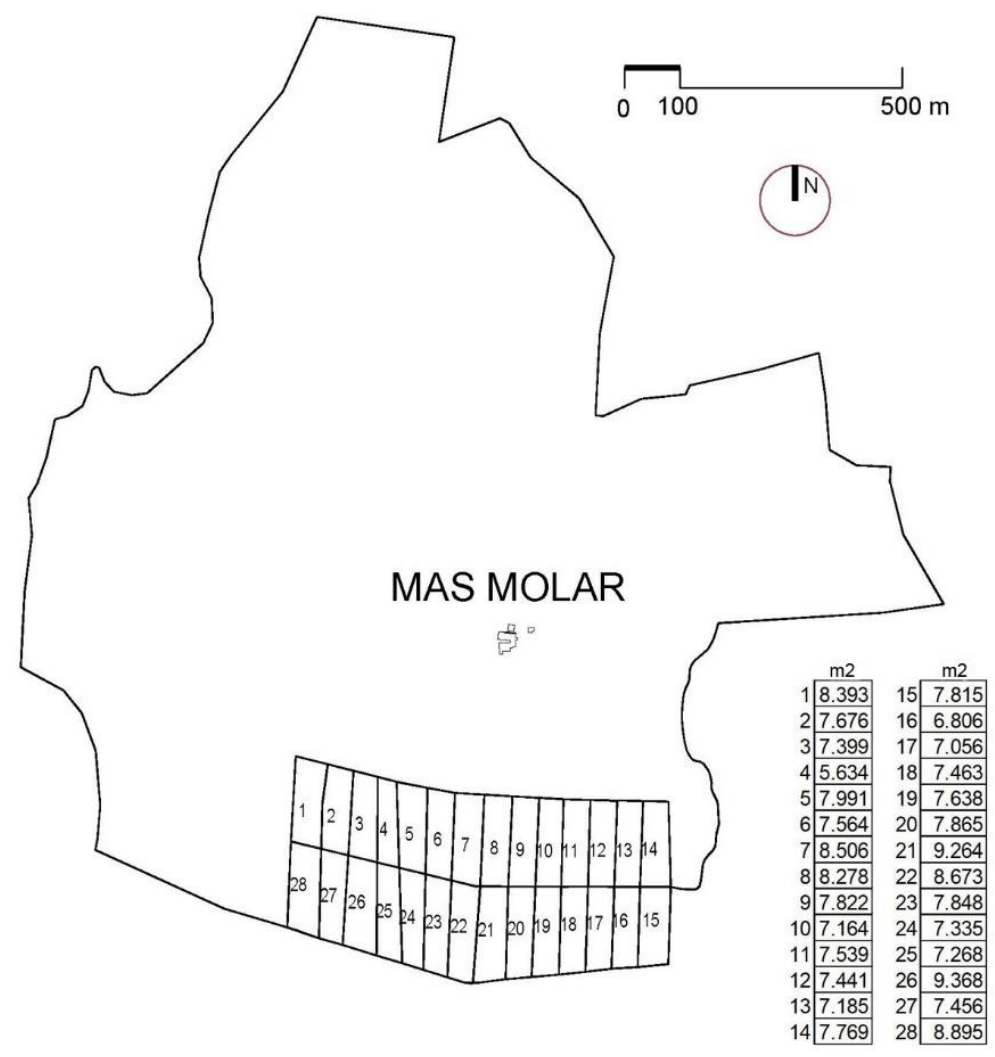

Fig. 2. Plot plan of Mas Molar in the mid nineteenth century (drawing R. Ripoll, private archive, 2020). 


\section{VARIABLE GEOMETRIZATION (TRADITIONAL LANDSCAPE)}

The facilities for buying or renting rural farmland in the nineteenth century in la Garriga d'Empordà are what led to the unique organization of this landscape (variable geometry). It was the result of a new type of landscape that developed between tradition and modernity, and is characterized by being dynamic (Bolòs, 2004), influenced by the organic evolution of social, economic, political and legal aspects and allowing continuous self-management; complex (Chouquer, 2000), defined due to reasons of geography, orientation and history that provide a wealth of morphology; and especially beneficial (Aston \& Philpin, 1988), based on the demand for land by rural workers that benefits variable incomes (beneficial ownership) and harms fixed incomes (legal title ownership).

Geometric freedom and territorial fragmentation, typical of the traditional world, serving the needs of each user in a direct, simple and measured manner. The morphological study area is specifically the central part of la Garriga d'Emporda $(6,338,138 \mathrm{~m} 2$ or 633 hectares). This area includes 316 properties (according to the current cadastre of 2020). The surface area of each farming unit is the result of the balance between supply and demand as well as productivity and financial cost of buying or renting. The harmonization of these four variants is what mainly defines their size. Thus, the most common plots are small (149 plots) of a surface area ranging from 2,100 to $10,500 \mathrm{~m} 2$ ( 1 to 5 vessanes), followed by medium-sized plots (90 plots) whose surface area ranges from 10,500 to $21,000 \mathrm{~m} 2$ ( 5 to 10 vessanes). To a lesser extent we find very small parcels (30 plots) of less than $2,100 \mathrm{~m} 2$ (1 vessana) and large plots (47 plots) over 21,000 $\mathrm{m} 2$. These sizes are intended to cover family consumption with surpluses being sold locally (Table 1). Most plot boundaries are marked by dry stone walls between 0.5 to $1 \mathrm{~m}$ in height.

\section{Parcel surface characteristics}

Table 1.

\begin{tabular}{|c|c|c|c|c|c|c|c|c|}
\hline \multirow[b]{3}{*}{$\begin{array}{l}\text { PLOTS } \\
(2.100 \mathrm{~m} 2=1 \text { "vessana") }\end{array}$} & \multicolumn{6}{|c|}{ MUNICIPALITIES } & \multirow{2}{*}{\multicolumn{2}{|c|}{ TOTALS }} \\
\hline & \multicolumn{2}{|c|}{ Avinyonet } & \multicolumn{2}{|r|}{ Llers } & \multicolumn{2}{|c|}{ Vilanant } & & \\
\hline & ut & $\mathrm{m} 2$ & ut & $\mathrm{m} 2$ & ut & $\mathrm{m} 2$ & ut & $\mathrm{m} 2$ \\
\hline $\begin{array}{l}\text { LARGE }>21.000 \mathrm{~m} 2 \\
(>10 \text { "vessanes" }) \\
\end{array}$ & 11 & 506.468 & 20 & 2.545 .890 & 16 & 989.010 & 47 & 4.041 .368 \\
\hline $\begin{array}{l}\text { MEDIUM: } 10.500 \text { to } 21.000 \mathrm{~m} 2 \\
\text { (5 to } 10 \text { "vessanes" ) }\end{array}$ & 20 & 307.788 & 48 & 699.782 & 22 & 297.590 & 90 & 1.305 .160 \\
\hline $\begin{array}{l}\text { SMALL: } 10.500 \text { a } 2.100 \mathrm{~m} 2 \\
\text { ( } 1 \text { to } 5 \text { "vessanes") } \\
\end{array}$ & 56 & 332.518 & 38 & 278.999 & 55 & 340.638 & 149 & 952.155 \\
\hline $\begin{array}{l}\text { VERY SMALL }<2.100 \mathrm{~m} 2 \\
(<1 \text { "vessana") }\end{array}$ & 14 & 18.303 & 4 & 8.172 & 12 & 12.980 & 30 & 39.455 \\
\hline
\end{tabular}

With regard to topography, there is a direct relationship between the gentle relief of la Garriga d'Empordà and the morphological organization of the plots. These parcels' contours range from $150 \mathrm{~m}$ to a height of $218 \mathrm{~m}$ above sea level (Fig. 3). Most plots are established in areas of little gradient ranging between 2 and 10\% (approximately three-fifths). The remainder are established on land on more pronounced gradients of between 10 and 20\% (approximately one-fifth) and the rest on slopes exceeding $20 \%$. In the latter case, the areas of greatest gradient, or areas with torrents, the gradient may range from 45 to $65 \%$, a feature that prevents the construction of terraces. At some points, there is a greater relationship between topography (contour) and plot (property shape). In this regard the relationship should be noted between the highest point in the area $(118.2 \mathrm{~m})$ and the 11 plots occupying it (around plots LL-63 and LL-64). Generally, gradients are smoothed by earth-retaining dry-stone walls of 0.5 to $1 \mathrm{~m}$ in height. 


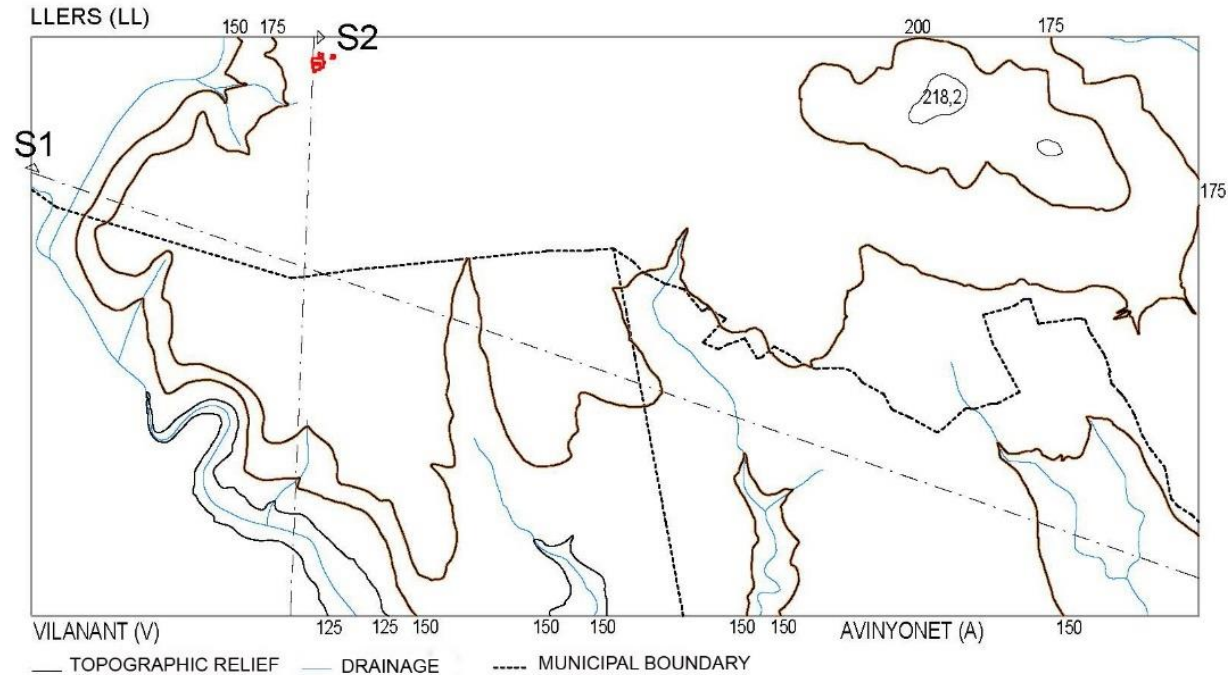

(11) $\overbrace{0} \longrightarrow \frac{100}{1} \mathrm{~m}$
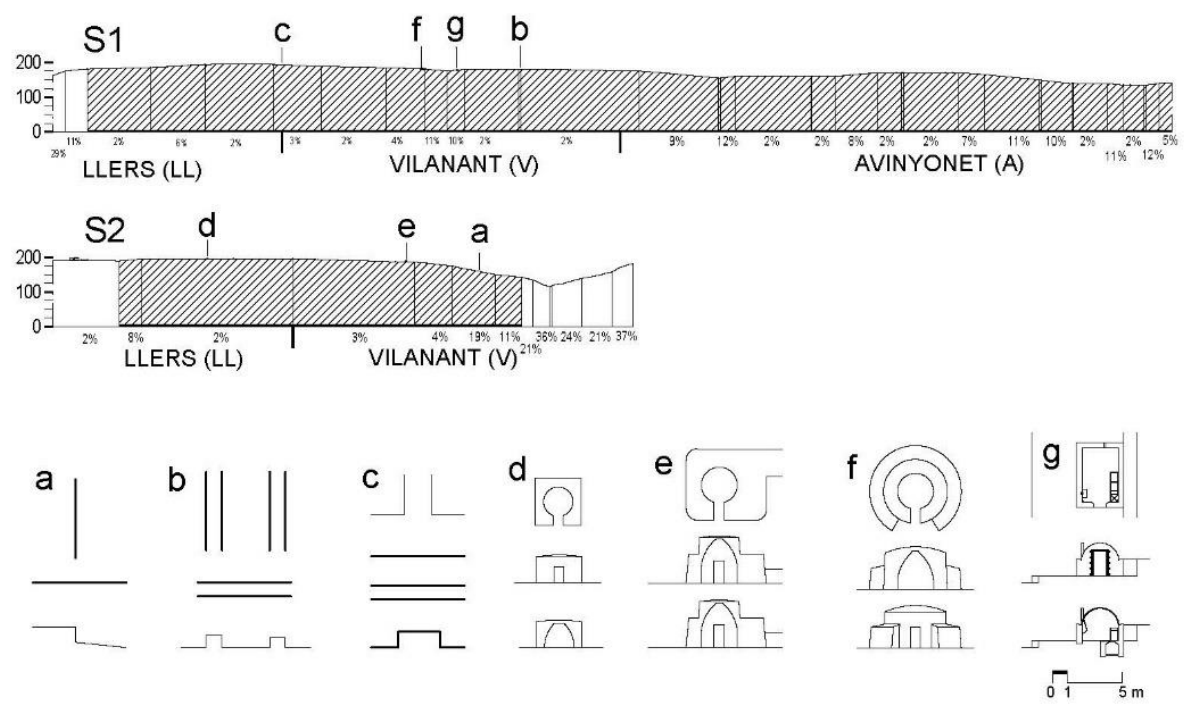

Fig. 3. Topographical study (drawing R. Ripoll, private archive, 2020).

Road access to the different properties is a third important aspect of the definition of variable morphology. We can identify one main road (wider than $3 \mathrm{~m}$ ) that connects the villages of Llers and Avinyonet de Puigventós (6 km long). Along this length (north to south) 37 plots (12\%) are organized and have access, creating an obvious morphological dependence between the shape of the plot and the road. The secondary roads (between 1.5 and $3 \mathrm{~m}$ wide) link most plots and are public. Most of these roadways are marked by dry stone walls of between 0.5 and $1 \mathrm{~m}$ in height. A third type of tertiary roadways (less than $1.5 \mathrm{~m}$ wide) provide access to the most isolated plots and arise from private agreements of passage between owners, or they take advantage of water drainage areas as thoroughfares. Finally, there is clear relationship between the municipal boundary line and the morphology of the plots that align with it. In this sense a total of 85 plots are recorded. So, the alignment of nearly one-third of properties (27\%) coincides with the municipal boundary line (Fig.4). 

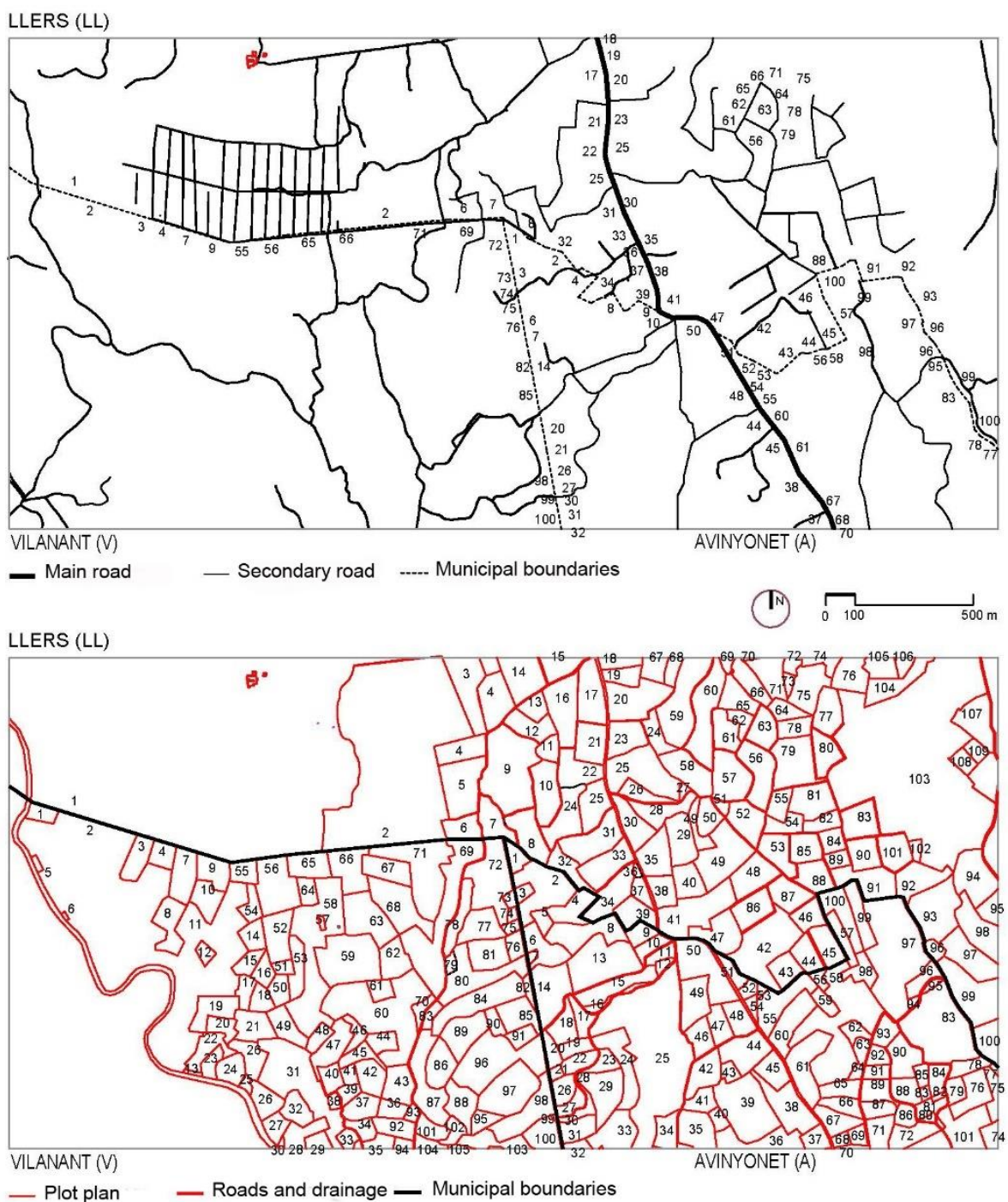

Fig. 4. Study of plots (drawing R. Ripoll, private archive, 2020).

\section{CONSTRUCTION TECHNIQUE (DRY STONE)}

The relationship between construction technique and the spatial organization of each plot is also evident. In this case, it is the owner or lessee of each parcel that examines, decides and carries out such organization. This self-build construction directly fuses agricultural function and construction technique. The technology used for construction creates retaining walls to facilitate the accumulation of earth, boundary walls to facilitate the accumulation of surplus stone, corbel vaults that facilitate the creation of domes with rings of horizontal stones that close successively, and finally vaults formed by an arch of dry-stone forming voussoirs, etc. These vaults allow building shacks for shelter against bad weather, especially for workers who are from neighbouring villages. The most common tools for working with dry stone are the mallet and the iron bar. These constructions were built by the owners and lessors of the piece of land themselves. Thus, the most common system of construction was selfbuilt, and the more experienced labourers even helped build walls and huts for other owners. 
The walls are begun directly on the ground, previously removing the surface layer of the terrain. They are erected with a slight slope on one side (earth retaining walls) or on both sides with rubble inside (in separating walls). In either case, the stones are each selected and placed geometrically to achieve maximum contact surface with each other, with the aid of wedges of smaller stones. In la Garriga d'Empordà, walls are not excessively high due to the slight gradients and the characteristics of the geometry of the stone, rendering it hard to position. Both its rounded shape and its high average compressive strength (66 Mpa) mean it is hard to work and hinder its direct use in construction. It should also be stated that there are no special additional elements in the walls as could be stairs, paving, doorways, ramps, etc. The role of the dry wall on each plot is clear (from 2 to 7 linear metres of wall per $\mathrm{m} 2$ of plot) creating different, unique solutions and compositions on each plot (Table 2).

Table 2.

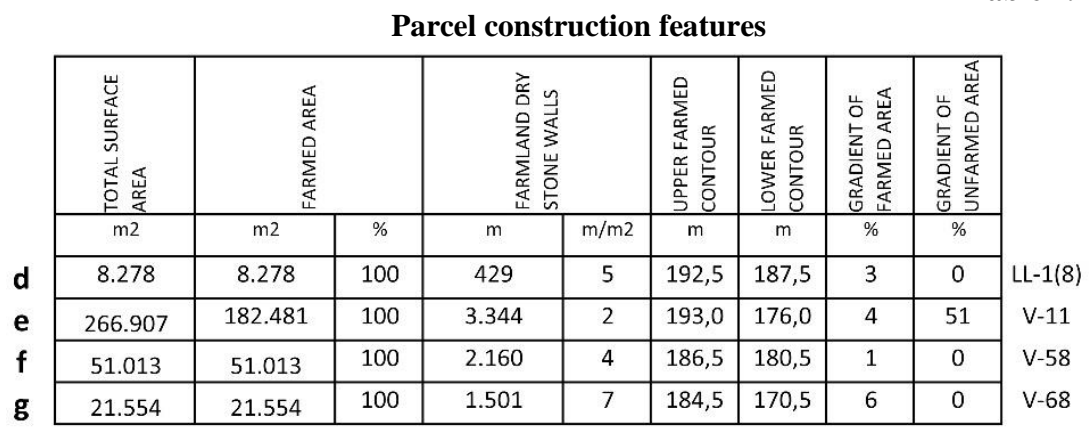

Most huts are built using a corbel vault. This is due to technical ease, the simplification of complementary means and speed of execution. Moreover, huts with voussoirs are located around quarry areas due to the availability of more skilled labour. Most of the huts have a circular interior floor plan (between 2 and $3 \mathrm{~m}$ in diameter) and are square as well as circular outside with thick walls (between 1 and $1.5 \mathrm{~m}$ ). To improve the stability of the huts, buttress walls are built around them (between 0.8 and $1.5 \mathrm{~m}$ wide) and crowns that reduce the weight of the dome forming rings, etc. (Fig. 5 \& Fig. 6).
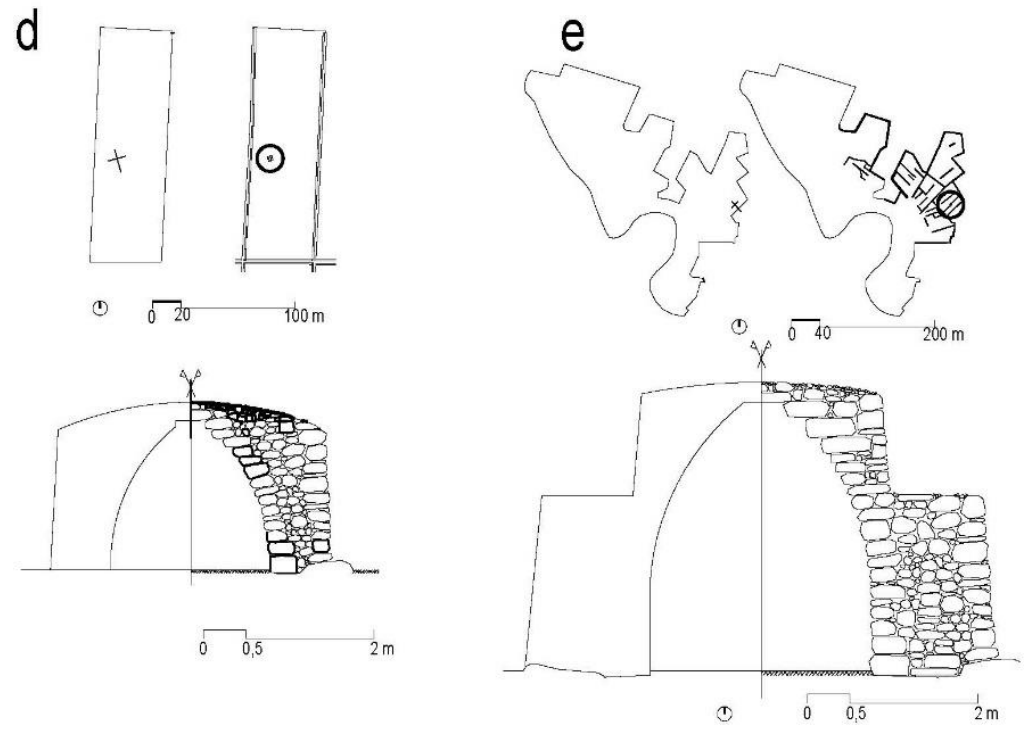

Fig. 5. Examples of constructions on plots d (LL-1(8)) and e (V-11)

(Drawing: R. Ripoll, p. archive, 2020). 

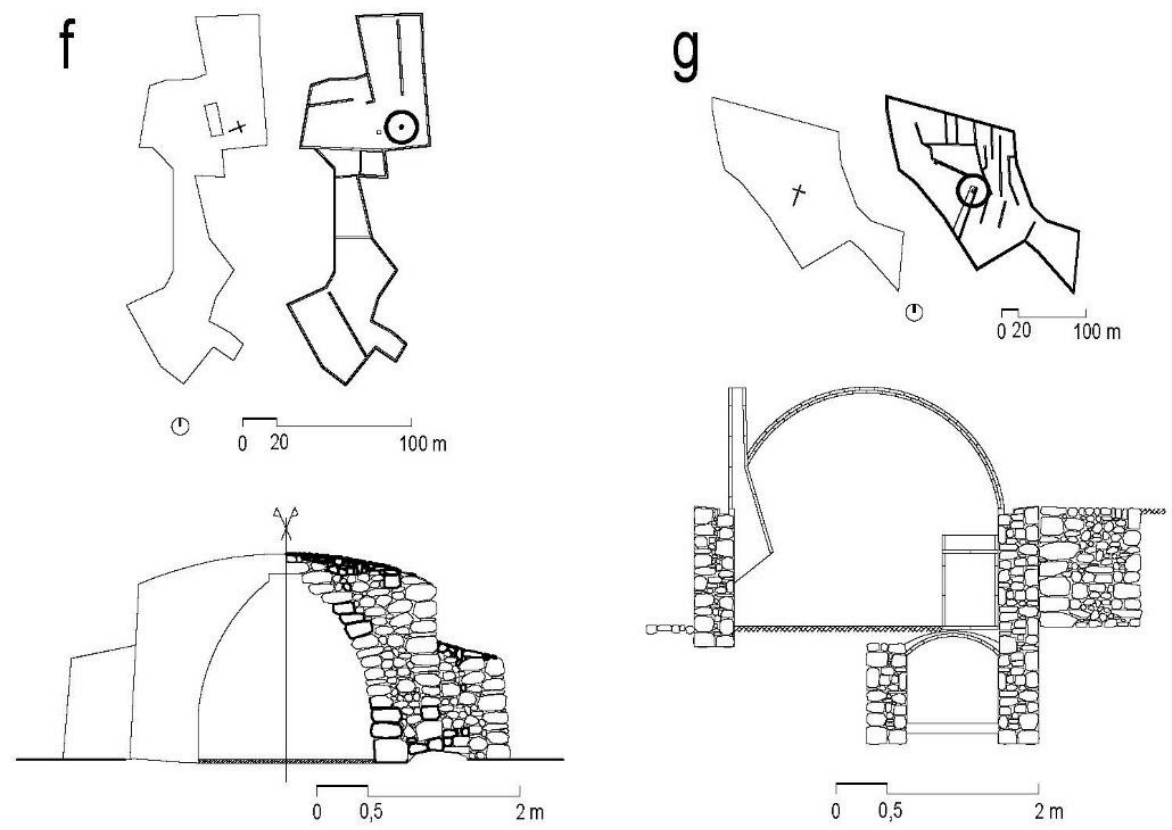

Fig. 6. Examples of constructions on plots $\mathrm{f}(\mathrm{V}-58)$ and $\mathrm{g}(\mathrm{V}-68)$

(Drawing: R. Ripoll, p. archive, 2020).

\section{CONCLUSION}

The relationship between traditional farmers and the physical characteristics of the site is clear and the building work carried out by farmers on the territory is demonstrated in this investigation. There is a direct relationship between the geographical environment, agricultural needs, local materials and technical means. This explains the coherent, cohesive, free and genuine morphology. Such a course of action involves some modification of the landscape and of the territory, like many places in the Mediterranean that have been developed in parallel and in similar fashion. The first conclusion is the importance of being familiar with, interpreting and using local stone which reduces transport costs (locally-sourced materials), production costs (the materials are used in their natural form), and the management and implementation time (self-building).

It can also be deduced that behind locally-sourced materials, natural forms and self-building, there is not just a material functional motivation (physical function) but also a personal motivation for self-realization (emotional function). We agree with authors that emphasize the self-management and self-confidence of traditional farmers (PLA, 1975, 156-7), but we disagree when this is limited to the merely mechanistic and economic aspect of the traditional agricultural landscape (PLA, 1968, 427). We can conclude that the harmonious, free transformation of landscape in la Garriga d'Empordà would not have been possible without deep (physical and mental) identification with the land. Then we can begin to say that the aesthetic of the enjoyment of the present landscape is rooted in the preindustrial traditional world.

According to the results, it can be stated that in the nineteenth century many transformations of the territory imply clearly present-day landscape values: well-managed and ordered, organic and dynamic, heterogeneous and diverse, harmonious and free, singular and unique, or productive and aesthetic. Other values can also be found: deep-rooted and dynamic, calm and free, respectful and enigmatic, and above all, that contribute to individual and social well-being. Management of the territory based on self-building with concepts typical of construction, architecture and the contemporary landscape such as the expressive force of the gravity or heaviness of forms (Campo, 2010,) and the biodiversity generated by dry stone constructions (Llagostera, 2014). 
These conclusions reaffirm that the transformation of la Garriga d'Empordà in the nineteenth century for poorer peasant families meant not only a minuscule means of material progress but above all a major means of social hope and human dignity.

\section{R E F E R E N C E S}

AHG, Comptadoria d'Hipoteques de Figueres (1841-1862). Girona: Arxiu històric de Girona.

Aalto, A. (1977). La humanización de la arquitectura. Barcelona: Tusquets editores.

Aguiló, M. (1999). El paisaje construido. Una aproximación a la idea de lugar. Madrid: Colegio de Ingenieros de caminos, canales y puertos.

Artigas, M, Sanguineti, J.J. (1993). Filosofia de la naturalesa. Pamplona: Eunsa.

Aston, T.H., Philpin, C.H.E. (1988). El debate Brenner. Estructura de classe agraria y desarrollo economico de la Europa preindustrial. Barcelona: Novagráfik.

Ballart, J. (2018). Paisaje y patrimonio. Madrid: Arqueologia Editorial.

Berque, A. (2009). El pensamiento paisajero. Madrid: Editorial Biblioteca Nueva.

Boada, M., Zahonero, A. (1999). Media ambient. Una crisi civilitzadora. Barcelona: Edicions de la Magrana.

Bolós, J. (2004). Els orígens medievals del paisatge català. L'arqueologia del paisatge com a font per a conèixer la història de Catalunya. Publicacions de l'Abadia de Montserrat. Barcelona.

Campo, A. (2010) Pensar con las manos. Buenos Aires: Editorial Nobuko.

Chouquer, G. (2000). L'étude des Paysages. Essais sur leurs formes et leur histoire. Paris: Edicions Errance.

Congost, R. (2008). Història agrària dels Països Catalans. Barcelona (III). Edicions de la universitat de Barcelona.

Congost, R. (2010). La pedra seca. Evolució, arquitectura i restauració. Figueres: Brau edicions.

Congost, R., To, Lluís (1999). Homes, masos, història. La Catalunya del nord-est (segles X-XX). Barcelona: Publicacions de l'Abadia de Montserrat.

De Bolós, M. (1992). Manual Ciencia del Paisaje. Teoría, étodos y aplicacions. Barcelona: Editorial Masson.

De Castro, C. (1997). Geografia en la vida cotidiana. De los mapas cognitivos al prejuicio regional. Barcelona: Ediciones del Serbal.

Fèlix, J. (2012). Les barraques de pedra seca de la Garriga d'Empordà. Figueres: Brau edicions.

Llagostera, S. (2014). VII Trobada d'estudi per a la preservació de la pedra seca als Països Catalans. Olot: Patronat d'Estudis històrics d'Olot i Comarca.

McHarg, Ian. (2000). Proyectar con la naturaleza. Barcelona: Gustavo Gili

Miralles, F., Marín, M., Montfort, J. (2002). Els homes i les pedres. La pedra seca a Vilafranca (Castelló): Un paisatge humanitzat. Castelló: Diputació de Castelló.

Pla, J. (1968). Viatge a la Catalunya Vella. Barcelona: Edicions Destino.

Pla, J. (1975). Els pagesos. Barcelona: Edicions Destino.

Terrades, I. (1984). El món històric de les masies. Barcelona: Curial. 